\title{
Evaluating Growth and Yield Parameters of Five Quinoa (Chenopodium quinoa W.) Genotypes Under Different Salt Stress Conditions
}

\author{
Asad Sarwar Qureshi ${ }^{1} \&$ Ashenafi Worku Daba ${ }^{2}$ \\ ${ }^{1}$ International Center for Biosaline Agriculture, Dubai, UAE \\ ${ }^{2}$ Ethiopian Institute of Agricultural Research, Ethiopia \\ Correspondence: Asad Sarwar Qureshi, International Center for Biosaline Agriculture (ICBA), P.O. Box 14660, \\ Dubai, UAE. Tel: 971-56-174-7731. E-mail: busyperson65@gmail.com
}

$\begin{array}{ll}\text { Received: December 10, } 2019 & \text { Accepted: January 13, } 2020 \quad \text { Online Published: February 15, } 2020 \\ \text { doi:10.5539/jas.v12n3p128 } & \text { URL: https://doi.org/10.5539/jas.v12n3p128 }\end{array}$

\begin{abstract}
Soil salinization is a global problem which restricts the choice of crop for cultivation. Management and reclamation of salinity using costly techniques may not be affordable by subsistence farmers. Therefore, it is important to look for new alternate crops like "quinoa" which are more salt-tolerant. As crops vary in their tolerance to salinity, they need to be evaluated for different salinity conditions. This study was conducted to evaluate five quinoa (Chenopodium quinoa W.) genotypes (ICBA-Q1, ICBA-Q2), ICBA-Q3, ICBA-Q4 and ICBA-Q5) for salinity tolerance under four artificially induced salinity $\left(5,10,15,20 \mathrm{dS} \mathrm{m}^{-1}\right)$ levels. The pot trials were conducted in a greenhouse, using $6 \mathrm{~kg}$ of Fluvisol soil in each pot. For comparison, trials were also conducted under field conditions. The parameters studied were rate of seed germination, plant height, fresh and dry biomass, chlorophyll content and grain yield. As expected, salinity had generally an inhibitory effect on all parameters. Out of the five quinoa varieties (ICBA-Q1 to ICBA-Q5), ICBA-Q3 and ICBA-Q4 proved to be more salt-tolerant. Therefore these two genotypes are recommended to farmers for large-scale adaptation.
\end{abstract}

Keywords: chlorophyll, germination, grain yield, quinoa, soil salinity, Ethiopia

\section{Introduction}

Increasing soil salinization has raised serious concerns of food security for the growing population of the world, which is expected to reach to 9 billion by 2050 (FAO, 2015). FAO estimated that over 1,000 million ha (mha) are globally affected by salinity and sodicity problems. Out of this, about 400 mha are saline, 450 mha are sodic and the remaining saline-sodic in nature (FAO, 2015). Currently, about 20\% (62 mha) of the global irrigated land (over $300 \mathrm{mha}$ ) is affected with salinity whereas an additional 2,000 ha are added to this menace annually (Qadir et al., 2014). The growing existence of saline soils is reducing natural biodiversity as well as farm and livestock productivity. It is also threatening the sustainability of irrigated agriculture, which produces more than $80 \%$ of the total grains. Therefore there is a strong need to control spread of soil salinization. The possible solutions include using physical practices such as improved soil-water-crop management or adopt biological practices such as introducing salt-tolerant species (Ashenafi \& Bob, 2016).

Ethiopia stands first in Africa in the extent of salt-affected soils with an estimated 11 mha of land exposed to salinity (Ashenafi \& Bob, 2016; Frew et al., 2015). This relates to 13\% of the total irrigated area of the country (Birhane, 2017). The saline soils are mainly located in the Rift Valley, Wabi Shebelle River Basin, the Denakil Plains and other lowlands of the country, where about $10 \%$ of the population lives (Sileshi, 2016). The problems of soil salinity are expected to increase in future due to the establishment of large-scale irrigation schemes without the provision of adequate drainage facilities (Birhane, 2017). The salinity problems have grave implications for the future food security and economic development of the country. With an annual population growth rate of $3 \%$, securing food and improving livelihood of the rising population will be the biggest challenge. Even today, food shortages are widespread and since 1970 country is in the grip of consistent famines. It is reported that among children aged up to 5 years, around $25 \%$ are underweight and $40 \%$ are stunted due to malnutrition (UNCEF, 2016).

In the Rift valley and other irrigated areas of Ethiopia, salinity development is mainly caused by the presence of soluble salts in the irrigation water, hot and dry weather conditions and excessive use of poor quality 
groundwater for irrigation. Development of large irrigation schemes in middle and lower Awash Valley without effective drainage systems along with poor water management practices have resulted in the gradual rise of saline groundwater. Due to high evapotranspiration, water evaporates from the soil surface leaving the salt behind causing secondary salinization in these areas (Frew et al., 2015). The farmers in Ethiopia are mainly using flood/basin methods to irrigate their poorly levelled fields. There is a tendency to over-irrigate because farmers usually do not have enough knowledge of actual crop water requirements. Therefore, if the current irrigation practices will continue, salinity problems will further exacerbate. Therefore there is an urgent need to take necessary measures to control spread of soil salinization.

In order to meet the future food security challenges, reclamation of existing saline soils and prevention of other areas from salinity development is of paramount importance. The low to medium salinity areas can be reclaimed through effective leaching and installation of appropriate drainage systems. However, these strategies are costly, time consuming and difficult to implement by farmers due to lack of financial resources and technical know-how (Qadir \& Oster, 2004). The highly saline soils can be reclaimed by using chemical amendments and/or adoption of biosaline approach. The biosaline approach entails introduction of salt-tolerant food and forage crops, which can withstand higher salinity levels. These integrated food and forage systems can help in increasing flexibility of smallholder farmers to feed their families and livestock. However, this approach requires selection of diverse food and forage species which have the capacity to resist salts present in the soil (Qureshi, 2017).

One such crop is Quinoa (Chenopodium quinoa Willd), which has emerged as an ideal crop for drought prone and salinized agricultural areas due to its high nutritious value and wide adaptability and ability to grow in harsh climatic conditions characterized by high temperatures and poor soil and water quality (Ruiz et al., 2014; Bazile et al., 2016; Chukar-Allah et al., 2016). Quinoa is grown in Andes region for centuries, however, its production and consumption outside the Andes is relatively new (Jacobsen, 2017). Currently, quinoa is grown in more than 90 countries. Today, 80 percent of the quinoa production comes from Bolivia and Peru whereas the remaining 20 percent is produced in all other countries (Bazile et al., 2016). Despite this rapid exposition, quinoa farming is still in "experimental phase" in many countries. The yield differences are huge ranging from 0.6 to $3.9 \mathrm{t} \mathrm{ha}^{-1}$ depending on soil, water and climatic conditions (Scalin \& Lewis, 2017). This clearly indicates the need for further research to develop varieties that can produce consistent yields under different agro-climatic conditions.

Quinoa has successfully been grown from non-saline to highly saline soils (15-20 $\mathrm{dS} \mathrm{m}^{-1}$ ) (Wilson et al., 2002; Bosque Sanchez, 2003; Adolf et al., 2012). At these salt levels other plant types either fail to grow or grow only poorly (Munns \& Tester, 2008; Shabala et al., 2013)). Besides being gluten free, quinoa grain is rich in proteins and essential amino acids such as lysine, threonine, methionine, and much needed unsaturated fatty acids (i.e., linoleic, oleic and linolenic), of minerals ( $\mathrm{Ca}, \mathrm{Fe}, \mathrm{Cu}, \mathrm{Zn}$ ) and vitamins (A, B2, C and E) (Vego-Galvez et al., 2010). Quinoa is a good source of calcium and is suitable for lactose-intolerant consumers and those allergic to gluten (Repo-Carrasco et al., 2003; Vega-Gálvez et al., 2010). The leaves of the plant are frequently eaten as a leafy green vegetable just like as spinach. It can also be used as a highly nutritious feed for animals.

Quinoa is new in African countries, currently passing through pilot testing and field trial stages. Quinoa could withstand temperatures from $-8{ }^{\circ} \mathrm{C}$ to $38{ }^{\circ} \mathrm{C}$, at sea level or 4,000 meters above, which makes it viable for different agro-ecological conditions (Scalin \& Lewis, 2017). The quinoa is heat sensitive and may encounter poor seed germination and crop establishment problems in very hot salt-affected areas (Chukar-Allah et al., 2016). In this study, response of five quinoa genotypes to different salinity levels (control, 5, 10, 15 and $20 \mathrm{dS}$ $\mathrm{m}^{-1}$ ) was evaluated with regard to agronomic parameters. It is envisaged that the outcome of this study will help in the selection of appropriate quinoa varieties for saline areas in different parts of Ethiopia.

\section{Materials and Methods}

\subsection{Study Area}

The experiments were conducted at the Werer Agricultural Research Center (WARC), Amibara, Ethiopia, which is located at $278 \mathrm{~km}$ to the east of Addis Ababa $\left(9^{\circ} 12^{\prime} 8^{\prime \prime} \mathrm{N}\right.$ latitude and $40^{\circ} 15^{\prime} 21^{\prime \prime} \mathrm{E}$ longitude). The study area is relatively flat with slope gradients of 1-2\% (Figure 1). The mean annual rainfall is $570 \mathrm{~mm}$ with a minimum and maximum temperatures of $19{ }^{\circ} \mathrm{C}$ and $34{ }^{\circ} \mathrm{C}$, respectively (Figure 2). Higher soil evaporation due to extreme temperatures causes the creation of saline soils and nutrient disparity in the soils causing poor plant growth. The Vertisols soil type of the area varies from silty clay to clay whereas the texture of the Fluvisols soils sandy loam to silty loam (Heluf, 1985; Wondimagegne \& Mnalku, 2012). 


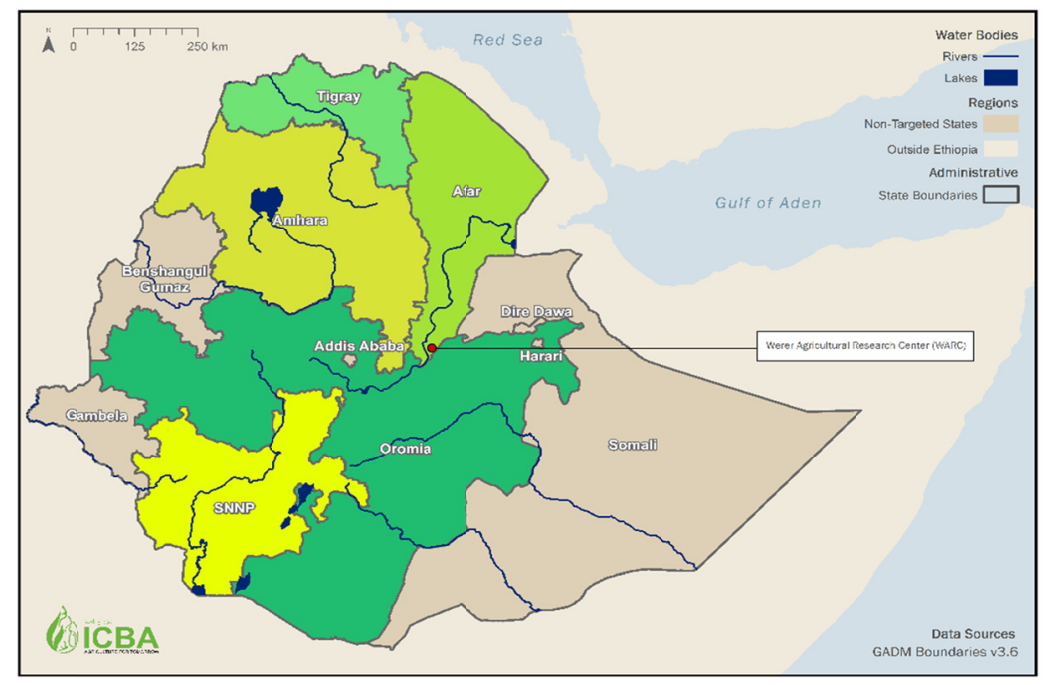

Figure 1. Location map of the study area

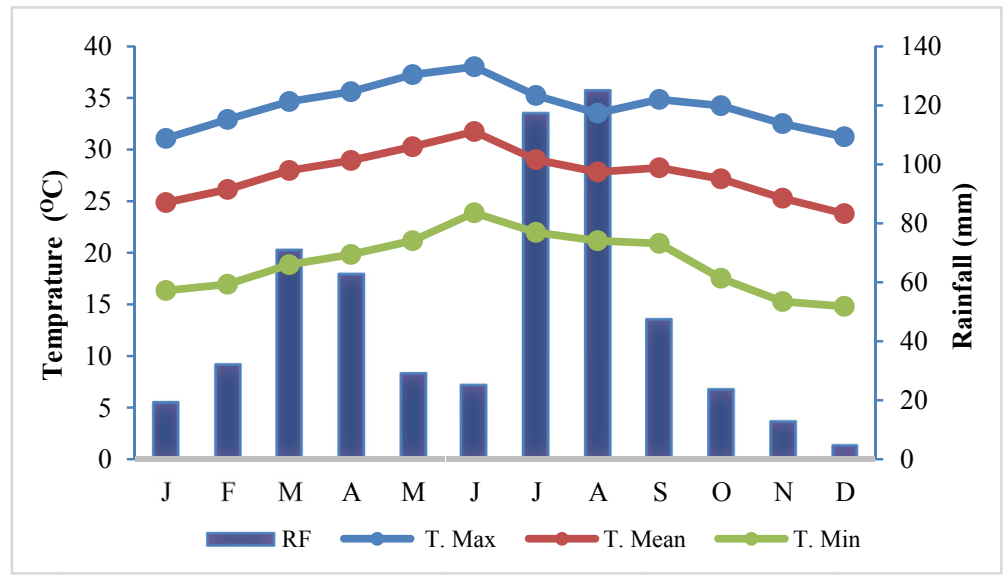

Figure 2. Mean monthly rainfall and minimum and maximum temperatures at the trial site

\subsection{Trials Under Controlled Conditions}

For pot trials under controlled conditions, treatments include two factors; food and forage genotypes and salt stress levels. The trials were conducted under 4 salt stress conditions to evaluate its suitability for different regions. Four salt stress treatments were prepared by mixing $7.2814 .57,21.43$ and $29.14 \mathrm{~g}$ of NaCl into $6.0 \mathrm{~kg}$ of soil packed per pot to produce salinity levels of $5,10,15$ and $20 \mathrm{dS} \mathrm{m}^{-1}$. Five quinoa genotypes (ICBA-Q1, ICBA-Q2, ICBA-Q3, ICBA-Q4, ICBA-Q5) were evaluated to test their performance under different soil salinity conditions. The treatments were organized in a completely randomized design with three replications.

Ten seeds of each genotype were sown in each pot. The seeds were surface sterilized using $70 \%$ ethanol (exposure for 10 seconds) followed by immersion for 10 minutes in sodium hypochlorite solution ( $\mathrm{NaClO} ; 5 \%$ active chloride). The treated seeds were washed thoroughly with distilled water and were placed on moist filter paper in petri dishes. Uniformity of seed size and quality was ensured before germination test. Irrigations were done with canal water $\left(\mathrm{EC}=0.3 \mathrm{dS} \mathrm{m}^{-1}\right)$.

\subsection{Trials Under Field Conditions}

Field trials were conducted on the saline-sodic soil with an average ECe value of $19.50 \mathrm{dS} \mathrm{m}^{-1}$ and an exchangeable sodium percentage (ESP) value of 20. A plot size of $3 \mathrm{~m} \times 4 \mathrm{~m}$ was used for field experiments. Soil samples were collected from $0-30 \mathrm{~cm}$ depth and analyzed for different soil parameters. The soil bulk density was determined according to the method described by Black (1965). The exchangeable bases (Ca, Mg, Na, and $\mathrm{K}$ ) were determined from the extraction of neutral normal ammonium acetate extraction, $\mathrm{Ca}$ and $\mathrm{Mg}$ from EDTA titration method, while $\mathrm{K}$ and $\mathrm{Na}$ using flame photometer. The cation exchange capacity (CEC) of soil was 
determined by the percolation tube procedure (Van Reewijk, 1992). The ESP was computed as the percentage of the exchangeable $\mathrm{Na}$ to the $\mathrm{CEC}$ of the soil (Table 1).

Table 1. Soil physio-chemical properties of the field trial site

\begin{tabular}{|c|c|c|c|c|c|c|c|c|c|}
\hline \multirow{2}{*}{ Quinoa genotypes } & \multirow{2}{*}{$\begin{array}{l}\text { Soil depth } \\
\text { (cm) }\end{array}$} & \multirow{2}{*}{$\mathrm{pH}$} & \multirow{2}{*}{$\begin{array}{l}\text { ECe } \\
\left(\mathrm{dS} \mathrm{m}^{-1}\right)\end{array}$} & \multicolumn{3}{|c|}{ Exchangeable bases $\left(\mathrm{cmol}_{(+)} \mathrm{kg}^{-1}\right)$} & \multirow{2}{*}{$\begin{array}{l}\text { CEC } \\
\left(\mathrm{cmol}_{(+)} \mathrm{kg}^{-1}\right)\end{array}$} & \multirow{2}{*}{$\begin{array}{l}\text { ESP } \\
(\%)\end{array}$} & \multirow{2}{*}{$\begin{array}{l}\mathrm{BD} \\
\left(\mathrm{g} \mathrm{cm}^{-3}\right)\end{array}$} \\
\hline & & & & $\mathrm{Ca}+\mathrm{Mg}$ & $\mathrm{Na}$ & $\mathrm{K}$ & & & \\
\hline ICBA-Q1 & $0-30$ & 7.9 & 19.32 & 36.94 & 8.00 & 1.04 & 41.16 & 19.44 & 1.38 \\
\hline ICBA-Q2 & $0-30$ & 7.8 & 20.34 & 43.02 & 7.68 & 0.96 & 44.21 & 17.37 & 1.36 \\
\hline ICBA-Q3 & $0-30$ & 8.0 & 20.01 & 38.83 & 9.67 & 1.01 & 39.83 & 21.28 & 1.37 \\
\hline ICBA-Q4 & $0-30$ & 8.1 & 18.76 & 37.91 & 9.01 & 0.98 & 41.78 & 21.57 & 1.39 \\
\hline ICBA-Q5 & $0-30$ & 7.9 & 18.98 & 38.02 & 8.98 & 0.87 & 43.57 & 20.61 & 1.36 \\
\hline
\end{tabular}

Since soils of the study area are good in nutrients therefore no fertilizer was used for experiments. Irrigations were given according to crop evapotranspiration (ETc), which was calculated by multiplying reference evapotranspiration (ETo) with the crop coefficient $(\mathrm{Kc})$. ETo was calculated using modified Penman-Monteith equation whereas the Kc values were taken from FAO-56 (Allen et al., 2006). In addition to total irrigation requirements according to ETc, an additional $10 \%$ of the total irrigation amount was applied for leaching of salts to manage root zone salinity.

\subsection{Observations and Measurements}

Mean germination time (MGT), germination percentage (GP), biomass and grain yield and shoot and root dry matter and other related data was measured. Seeds with full radicle were considered as germinated. Germination count was done on $5^{\text {th }}, 10^{\text {th }}$ and $15^{\text {th }}$ day after plantation. GP was calculated according to Ashraf and Foolad (2005) whereas MGT was determined using equation of Ellis and Roberts (1981). Chlorophyll content (SPAD units) of leaves was measured using Minolta Soil-Plant-Analysis Development (SPAD) meter. Plant height was measured with a standard ruler (i.e., stem length from soil level to the top of the flower head).

$$
\begin{gathered}
\mathrm{GP}=\frac{\text { Total germinated seeds }}{\text { Total number of seeds }} \\
\mathrm{MGT}=\frac{\sum \text { Dn }}{\sum \mathrm{n}}
\end{gathered}
$$

Where, $n=$ Number of germinated seeds on day $\mathrm{D}$, and $D=$ Number of days from the start of germination.

\subsection{Statistical Analysis}

Field and pot experiments were conducted for two years (2017-18) and the data was subjected to analysis of variance (ANOVA) technique (A. Gomez \& H. Gomez, 1984) for factorial CRD using SAS 9.3 software (SAS Institute, Cary, NC). The significance of differences between the mean values at $p<0.05$ was determined using Least Significance Difference (LCD) test. The comparison between all data obtained was made by using Duncan's Multiple Range Test (DMRT).

\section{Results}

\subsection{Trials Under Controlled Conditions}

\subsubsection{Germination Percentage (GP), Mean Germination Time (MGT) and Germination Index (GI)}

For all genotypes, increasing salinity affected seed germination. The GP was highest in ICBA-Q3, ICBA-Q4 and ICBA-Q5 in control and gradually decreased with the increasing salinity. The lowest GP was found in ICBA-Q1 and ICBA-Q2. The MGT also increased with growing salinity levels. The highest MGT was recorded in ICBA-Q1 at $20 \mathrm{dS} \mathrm{m}^{-1}$, followed by ICBA-Q2 whereas the lowest was found in ICBA-Q3 in control. MGT for other three genotypes were comparable (Table 2). The GI followed the trends of GP for all genotypes. The maximum GI was observed in ICBA-Q5 followed by ICBA-Q3 and ICBA-Q4 at control. Lower GI values were observed at the highest salt concentration levels for all genotypes. 
Table 2. Effects of salinity on GP, MGT and GI of five quinoa genotypes

\begin{tabular}{|c|c|c|c|c|c|c|c|c|}
\hline \multirow{2}{*}{ Parameters } & \multirow{2}{*}{ Genotypes } & \multicolumn{5}{|c|}{$\mathrm{NaCl}$ salt level $\left(\mathrm{dS} \mathrm{m}^{-1}\right)$} & \multirow{2}{*}{$\begin{array}{l}\text { LSD } \\
(p \leq 0.05)\end{array}$} & \multirow{2}{*}{$\mathrm{CV}(\%)$} \\
\hline & & 0 & 5 & 10 & 15 & 20 & & \\
\hline \multirow{5}{*}{ Germination Percentage (\%) } & ICBA-Q1 & 36.67 & 23.33 & 10.00 & 16.67 & 10.00 & \multirow{5}{*}{6.00} & \multirow{5}{*}{17.93} \\
\hline & ICBA-Q2 & 16.67 & 16.67 & 13.33 & 20.00 & 16.67 & & \\
\hline & ICBA-Q3 & 83.33 & 80.00 & 63.33 & 53.33 & 33.33 & & \\
\hline & ICBA-Q4 & 83.33 & 83.33 & 56.67 & 60.00 & 40.00 & & \\
\hline & ICBA-Q5 & 83.33 & 86.67 & 63.33 & 53.33 & 36.67 & & \\
\hline \multirow{5}{*}{ Mean Germination Time (days) } & ICBA-Q1 & 2.67 & 3.27 & 5.88 & 8.33 & 13.05 & \multirow{5}{*}{0.52} & \multirow{5}{*}{11.28} \\
\hline & ICBA-Q2 & 3.11 & 3.33 & 5.66 & 8.50 & 12.33 & & \\
\hline & ICBA-Q3 & 2.61 & 3.83 & 5.27 & 5.77 & 10.27 & & \\
\hline & ICBA-Q4 & 3.00 & 4.33 & 5.61 & 7.22 & 10.94 & & \\
\hline & ICBA-Q5 & 3.16 & 4.33 & 5.67 & 8.07 & 10.27 & & \\
\hline \multirow{5}{*}{ Germination Index (GI) } & ICBA-Q1 & 1.01 & 0.45 & 0.23 & 0.24 & 0.10 & \multirow{5}{*}{0.22} & \multirow{5}{*}{26.84} \\
\hline & ICBA-Q2 & 0.31 & 0.21 & 0.19 & 0.23 & 0.24 & & \\
\hline & ICBA-Q3 & 2.38 & 2.17 & 1.57 & 0.95 & 0.72 & & \\
\hline & ICBA-Q4 & 2.02 & 2.32 & 2.01 & 1.10 & 0.76 & & \\
\hline & ICBA-Q5 & 2.59 & 2.51 & 1.92 & 1.25 & 0.94 & & \\
\hline
\end{tabular}

\subsubsection{Plant Height}

For all quinoa genotypes, a decreasing trend in plant height was observed with the increasing level of salinity. The highest plant height was observed for ICBA-Q3 $(92.7 \mathrm{~cm})$ and ICBA-Q4 $(92.3 \mathrm{~cm})$ at $0 \mathrm{dS} \mathrm{m}^{-1}$. However, at higher salinity level $\left(20 \mathrm{dS} \mathrm{m}^{-1}\right)$, plant heights of ICBA-Q3 and ICBA-Q4 were reduced to $54.6 \mathrm{~cm}$ and $51.0 \mathrm{~cm}$, respectively. Increase in salinity from 0 to $20 \mathrm{dS} \mathrm{m}^{-1}$ causes reduction in plant height of for ICBA-Q3 and ICBA-Q4 by $41 \%$ and $44 \%$, respectively. Table 3 shows that plant height of all quinoa genotypes reduced significantly after $10 \mathrm{dS} \mathrm{m}^{-1}$. These results agree with those of Jacobsen (2003) and Al-Dakheel et al. (2015) who found significant reduction in plant height with the increasing salinity levels in Phaseolus species and Lentils.

Table 3. Effects of salinity on plant height of five quinoa genotypes

\begin{tabular}{lllllllll}
\hline \multirow{2}{*}{ Parameters } & Genotypes & \multicolumn{6}{c}{ NaCl salt level $\left.(\mathrm{dS} \mathrm{m})^{-1}\right)$} & \multicolumn{2}{c}{$\begin{array}{l}\text { LSD } \\
(\mathrm{p} \leq 0.05)\end{array}$} & CV (\%) \\
\cline { 3 - 6 } & & 0 & 5 & 10 & 15 & 20 & \\
\hline \multirow{3}{*}{ Plant height $(\mathrm{cm})$} & ICBA-Q1 & 68.67 & 67.00 & 67.67 & 61.67 & 42.47 & & \\
& ICBA-Q2 & 68.33 & 67.67 & 67.33 & 63.67 & 45.67 & & \\
& ICBA-Q3 & 92.67 & 84.00 & 74.67 & 63.00 & 54.66 & 4.01 & 8.05 \\
& ICBA-Q4 & 92.33 & 85.00 & 69.47 & 59.33 & 51.00 & & \\
\hline
\end{tabular}

\subsubsection{Dry Biomass Yield}

Dry biomass yield was attained by oven-drying fresh biomass at $65{ }^{\circ} \mathrm{C}$ to constant weight. In all quinoa genotypes, dry biomass yield conceded due to increased salt stress (Figure 3). The highest dry biomass yield was obtained in ICBA-Q3 at $0-5 \mathrm{dS} \mathrm{m}^{-1}$ whereas the lowest was obtained in ICBA-Q1 and ICBA-Q2. ICBA-Q4 performed better at elevated salinity levels $\left(15-20 \mathrm{dS} \mathrm{m}^{-1}\right)$. The dry biomass yield decreased with the increasing soil salinity in the growth medium, although the response of all five genotypes to different salinity levels was heterogeneous. At $0 \mathrm{dS} \mathrm{m}^{-1}$, dry biomass yield of ICBA-Q1, ICBA-Q2, ICBA-Q3, ICBA-Q4, and ICBA-Q5 was 15.5, 12.5, 29.6, 25.0 and $21.0 \mathrm{~g} / \mathrm{plant}$, respectively. However, the dry biomass yield at $20 \mathrm{dS} \mathrm{m}^{-1}$ was noted as $5.1,8.6,17.1,18.1$, and $13.5 \mathrm{~g}$ /plant, registering a reduction of $67 \%, 30 \%, 42 \%, 28 \%, 36 \%$ for ICBA-Q1, ICBA-Q2, ICBA-Q3, ICBA-Q4, and ICBA-Q5, respectively. For all salinity levels, minimum reduction was noted in ICBA-Q3, which shows that this genotype is most resistant to increasing salinity levels. 


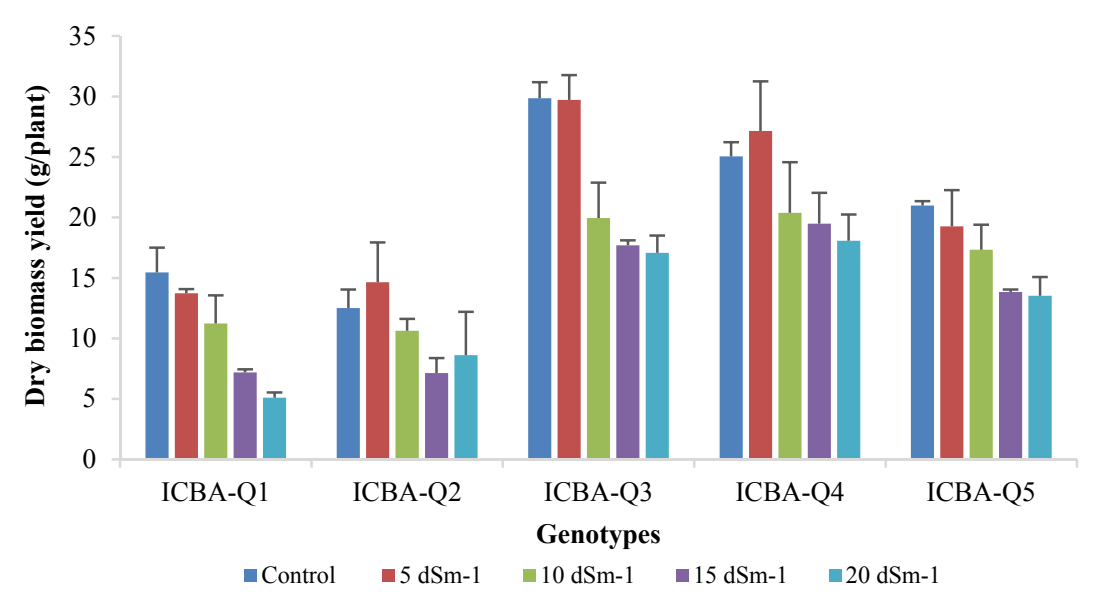

Figure 3. Dry biomass yield of five quinoa genotypes as affected by different salinity levels

The experimental data was also used to develop production functions for 5 quinoa genotypes under different soil salinity levels and the results are presented in Figure 4. The highest reduction in dry biomass yield per unit increase in salinity $\left(1 \mathrm{dS} \mathrm{m}^{-1}\right)$ was observed in ICBA-Q3 $(0.56 \mathrm{~g} / \mathrm{plant})$ followed by ICBA-Q1 $(0.48 \mathrm{~g} / \mathrm{plant})$ and ICBA-Q2 (0.46 g/plant). The lowest reduction in dry biomass per unit increase in salinity was found in ICBA-Q4 (0.38 g/plant) and ICBA-Q5 (0.22 g/plant). These two genotypes showed more stable dry biomass yields under all salinity levels. The dry biomass yield for ICBA-Q3 sharply declined after $5 \mathrm{dS} \mathrm{m}^{-1}$ salinity level whereas this was not the case for ICBA-Q4 and ICBA-Q5. ICBA-Q5 showed more consistent dry biomass yield at all salinity levels. This shows that under moderate salinity levels $\left(0-5 \mathrm{dS} \mathrm{m}^{-1}\right)$, ICBA-Q3 can be a good choice because of high yielding potential. However, for higher salinity levels (10-20 dS m $\left.{ }^{-1}\right)$, ICBA-Q4 and ICBA-Q5 are more suitable due to their higher salt tolerance capacity.
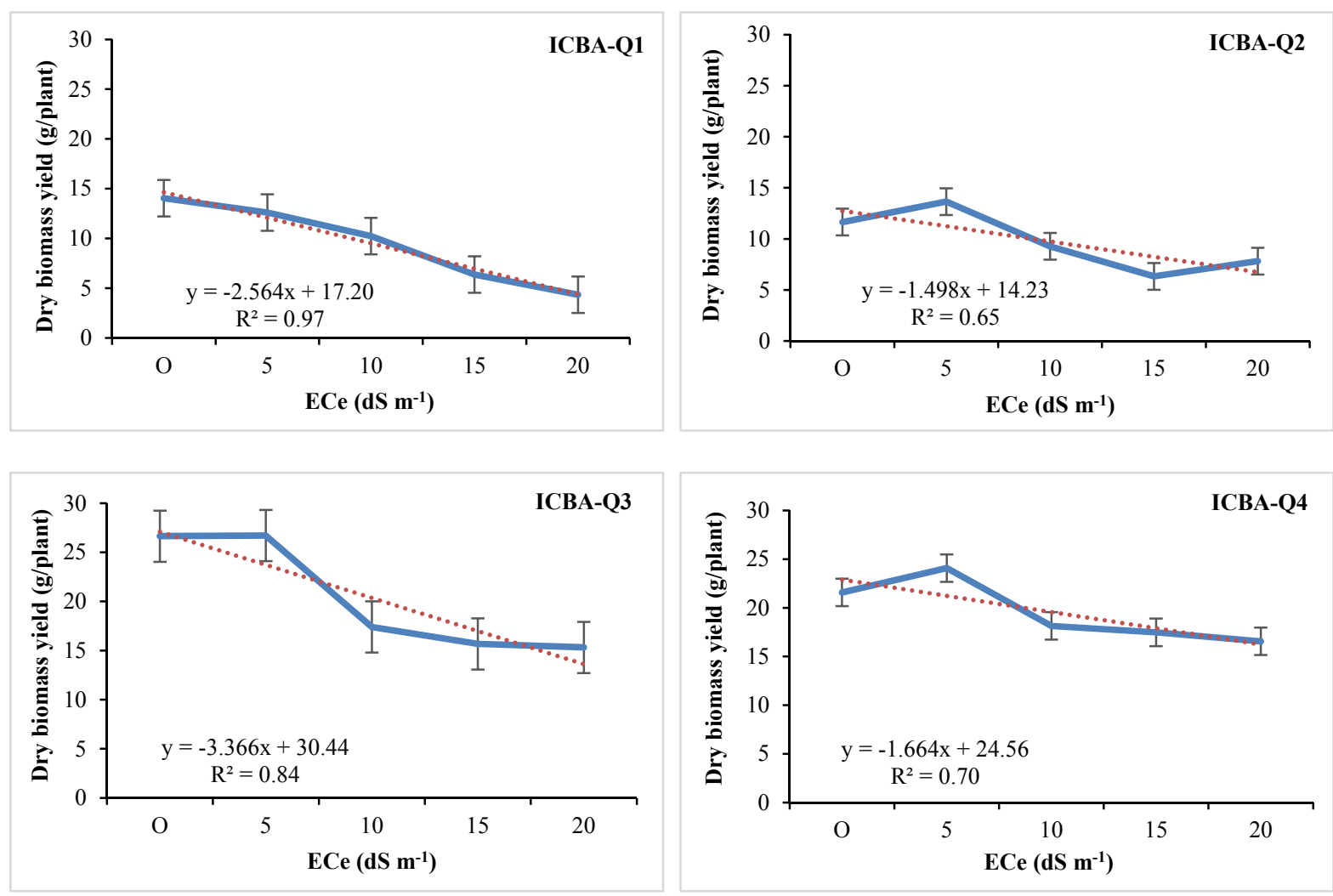


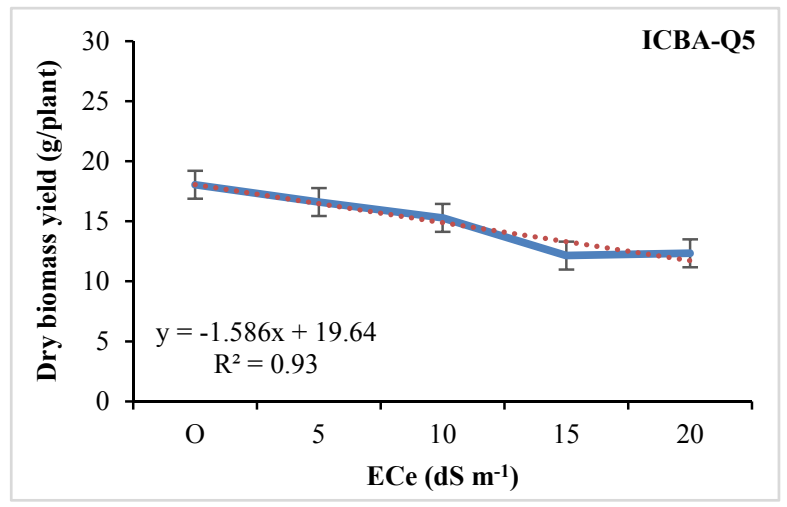

Figure 4. Dry biomass yield of five quinoa genotypes as effected by different salinity levels

\subsubsection{Grain Yield}

The grain yield was negatively affected by increasing salinity levels however, the impact was more noticeable at higher salt concentrations (Figure 5). Since ICBA-Q1 and ICBA-Q2 were poor in germination, they also produced lower grain yield. The highest grain yield was obtained for ICBA-Q3 at all salinity levels followed by ICBA-Q4 and ICBA-Q5. The differences in grain yields under ICBA-Q3 and ICBA-Q4 were non-significant. Under control, the grain yield of ICBA-Q4 and ICBA-Q5 was $10 \%$ and $42.5 \%$ less than the grain yield of ICBA-Q3. However, the reductions in grain yields at the higher salinity levels were comparatively lower than the control i.e., grain yields of ICBA-Q4 and ICBA-Q5 were 4.8\% and 38\% less than ICBA-Q3. The grain yields of ICBA-Q3 and ICBA-Q4 were comparable at $10-15 \mathrm{dS} \mathrm{m}^{-1}$, however, there was a significant reduction in grain yields at higher salinity level $\left(20 \mathrm{dS} \mathrm{m}^{-1}\right)$.

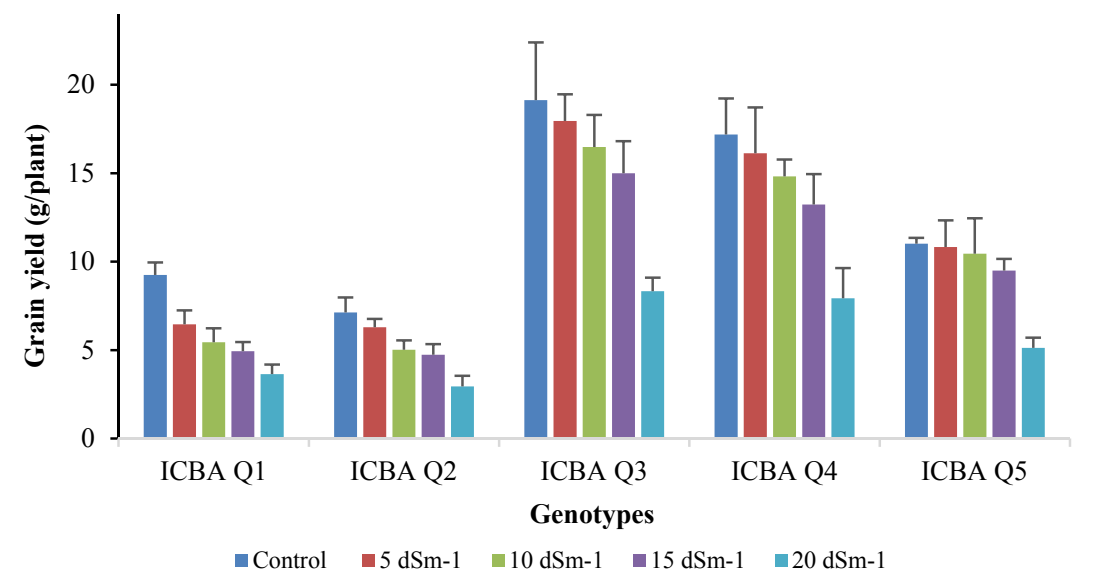

Figure 5. Grain yield of five quinoa genotypes as effected by different salinity levels

Figure 6 shows that the maximum reduction in grain yield per unit increase of salinity was recorded for ICBA-Q3 genotype followed by ICBA-Q4 genotype. Although ICBA-Q1 and ICBA-Q2 genotypes produced lower yields, the reduction in grain yield per unit increase in salinity for these genotypes was lower, e.g., 0.28 $\mathrm{g} /$ plant for ICBA-Q1 and $0.21 \mathrm{~g} / \mathrm{plant}$ for ICBA-Q2. The yield reduction per unit increase in salinity in ICBA-Q5 was $0.35 \mathrm{~g} /$ plant. Considering the overall dry biomass yield, grain yield and tolerance against higher salinity levels, ICBA-Q3 and ICBA-Q4 can be considered as the best genotype for all salinity levels under Ethiopian conditions. 

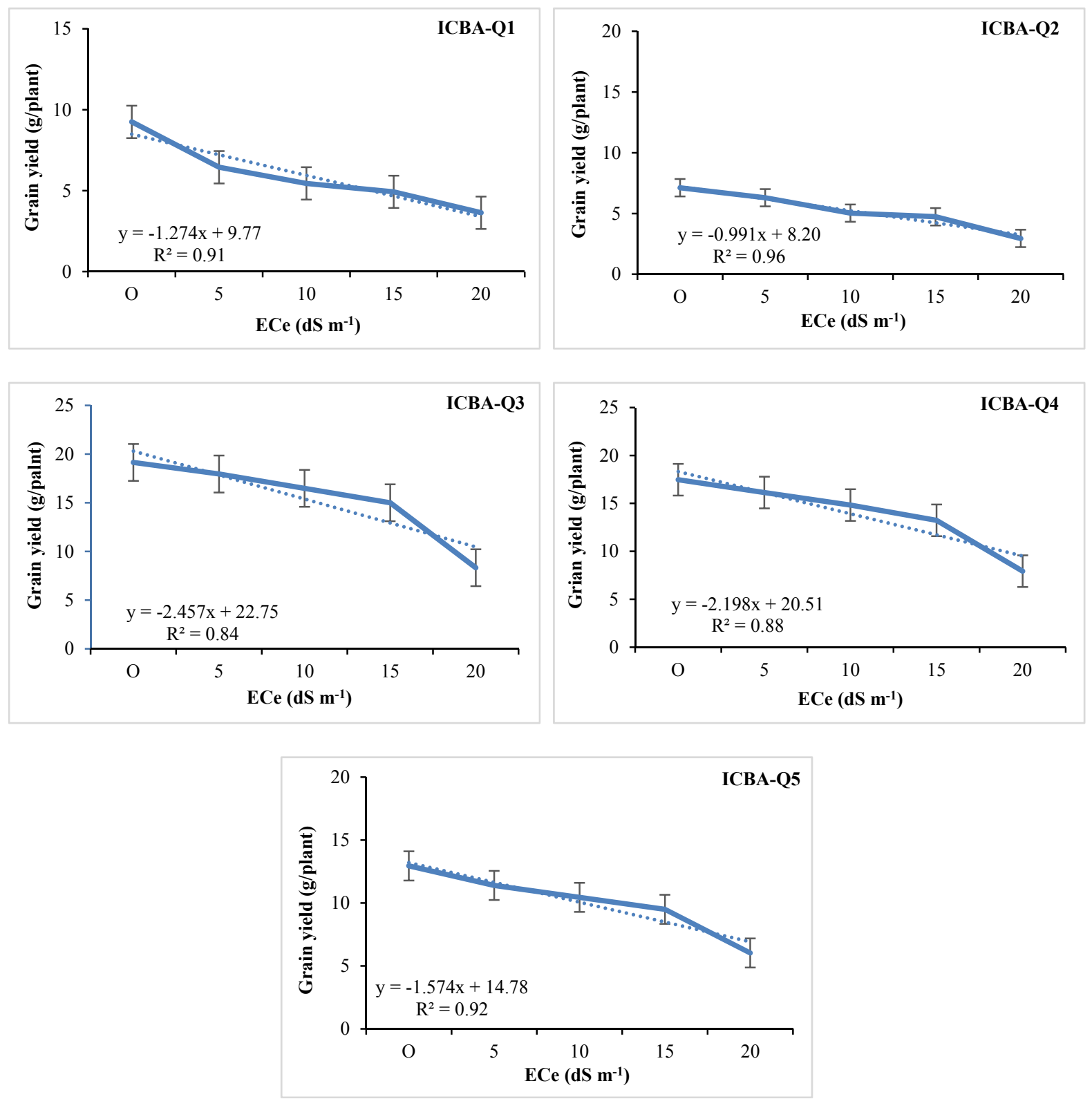

Figure 6. Grain yield of five Quinoa genotypes as affected by different salinity levels

\subsubsection{Chlorophyll Content}

Due to the distinct variation among all five quinoa genotypes, their responses to different salinity regimes for chlorophyll content were also different. Figure 7 illustrates that the chlorophyll content of all five genotypes tolerated salinity stress up to $10 \mathrm{dS} \mathrm{m}^{-1}$ but decreased significantly at higher salinity levels. The highest chlorophyll content was recorded at salinity levels of $0-5 \mathrm{dS} \mathrm{m}^{-1}$. The results indicate a decreasing trend of chlorophyll content with increasing salinity stress except in ICBA-Q2, ICBA-Q4, and ICBA-Q5 where chlorophyll content was higher at $5 \mathrm{dS} \mathrm{m}^{-1}$ compared to control. At lower salinity levels $\left(0-5 \mathrm{dS} \mathrm{m}^{-1}\right)$, the performance of ICBA-Q4 and ICBA-Q5 was superior than other three genotypes. Net decrease in the photosynthesis rates of quinoa by high salinity has also been reported (Eisa et al., 2017). They have also reported salt-induced growth reduction due to low photosynthetic supply because of impaired photosynthetic capacity. 


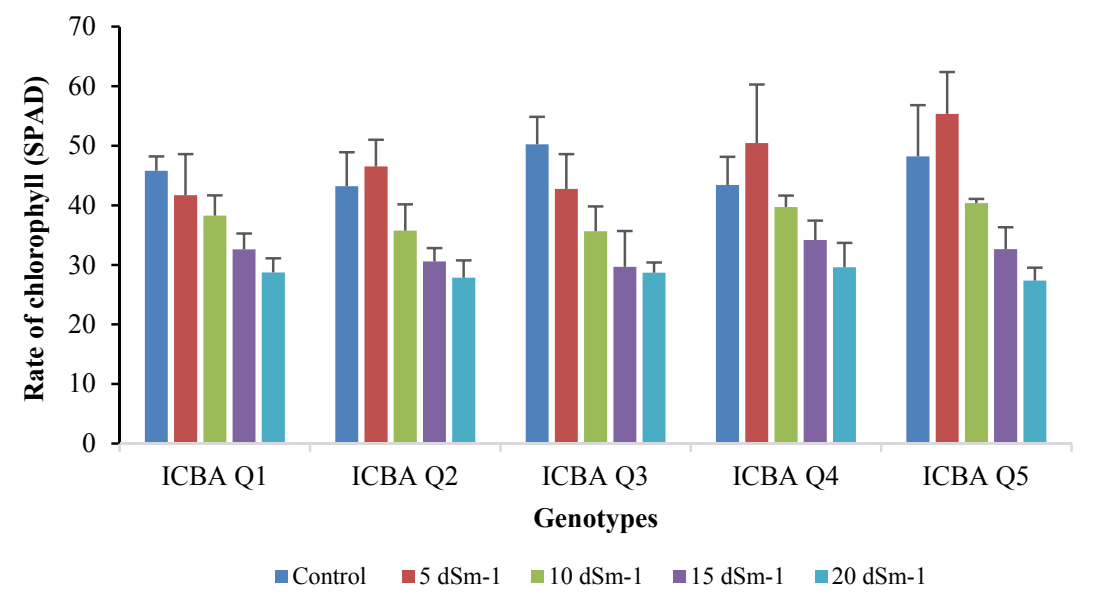

Figure 7. Chlorophyll rate of 5 quinoa genotypes as effected by different salinity levels

\subsection{Trials Under Field Conditions}

For the validation of pot trials results, selected five quinoa genotypes were also tested under field conditions with soil salinity (ECe) values approaching $20 \mathrm{dS} \mathrm{m}^{-1}$ (Table 4). The tested quinoa genotypes were found to be significantly different in biophysical parameters such as grain yield, days of $50 \%$ physiological maturity, days of $50 \%$ emergency, number of panicles per plant, plant height, number of days to pasty grain and milky stage and dry biomass yield. The results indicate that ICBA-Q3 performed superior with regard to grain and dry biomass yield followed by ICBA-Q4. The performance of ICBA-Q1 and ICBA-Q2 was the poorest under field conditions whereas ICBA-Q4 and ICBA-Q5 showed medium results. The field evaluation shows that ICBA-Q3 is the most suitable genotype for hot, dry and highly saline areas both in terms of dry biomass and the grain yield. As evident from the pot trial analysis, other genotypes such as ICBA-Q4 and ICBA-Q5 can yield satisfactory results in low to medium saline areas. Therefore, quinoa genotype for a certain area should be selected after due consideration of climatic and soil salinity conditions.

Table 4. Field evaluation of five salt-tolerant quinoa genotypes

\begin{tabular}{lllllllll}
\hline Quinoa genotypes & DE (days) & DM (days) & PH $(\mathrm{cm})$ & PPP (days) & DMS (days) & DPG (days) & DBY (ton/ha) & GY $(\mathrm{kg} / \mathrm{ha})$ \\
\hline ICBA-Q1 & 12.33 & 93.00 & 138.60 & 8.00 & 80.00 & 90.67 & 1.239 & 464 \\
ICBA-Q2 & 12.00 & 94.33 & 148.77 & 8.00 & 78.33 & 89.67 & 1.291 & 499 \\
ICBA-Q3 & 9.00 & 86.33 & 144.00 & 11.67 & 72.33 & 84.00 & 7.211 & 2965 \\
ICBA-Q4 & 8.67 & 89.00 & 152.13 & 10.00 & 75.67 & 88.00 & 5.885 & 1644 \\
ICBA-Q5 & 8.67 & 86.00 & 156.13 & 9.00 & 71.33 & 78.66 & 4.023 & 1559 \\
LSD (P < 0.05) & 1.49 & 3.94 & NS & 1.41 & NS & 6.68 & 0.572 & 152 \\
CV (\%) & 7.85 & 12.33 & 23.61 & 8.06 & 16.85 & 14.11 & 8.61 & 15.67 \\
\hline
\end{tabular}

Note. DE $=$ Days to $50 \%$ Emergence; DM $=$ Days to $50 \%$ Maturity; $\mathrm{PH}=$ Plant Height; PPP $=$ Panicles per Plant; $\mathrm{DMS}=$ Days to Milky Stage; DPG = Days to Pasty Grain; DBY = Dry Biomass Yield; GY = Grain Yield.

\section{Discussion}

The rising global demand for nutritious and healthy food has challenged scientists to look for alternate crops especially for the marginal areas where agricultural production is inefficient due to unfavorable climatic conditions, low soil fertility and lack of good quality irrigation water. In many countries of the Middle East and Africa region, scientists are experimenting quinoa production because it is rich in nutrients, tolerant to salinity and uses much less water than other crops. Against this backdrop, this study was focused on assessing the feasibility of 5 different quinoa genotypes for dry and saline soil conditions of Ethiopia under controlled and field conditions. The seed germination was adversely affected by the rising salinity. The salinity impedes seed germination either without loss of viability at higher salinities and/or by inducing stress to seeds (Breusegen et al., 2006). Gómez-Pando et al. (2010) did a study on 15 most salt-tolerant Peruvian accessions of quinoa and found that some genotypes of quinoa showed decline in germination and plant height under high saline conditions, while others did not or even register an increase. 
The results indicate reduction in dry biomass yield with increasing salinity, which might be due to lack of water availability and hydrolysis of reserved foods and their translocation to the growing shoots. Other factors responsible for lower dry biomass yield may include panicle length, chlorophyll concentrations, number of productive tillers, number of primary branches per panicle, and fertility percentage (Ali et al., 2004). Studies have also reported reduction in plant growth and dry-matter accumulation under saline conditions in several grain legumes including P. vulgaris that can be ascribed by decrease in cell elongation (Turan et al., 2007; Gómez-Pando et al., 2010).

Gómez-Pando et al. (2010) have also found a remarkable influence of quinoa genotypes on root dry mass per plant under saline conditions. This was probably due to the stunted growth of plants caused by high salt concentration in the nutrient medium. The higher salt stress causes reduction in the rate of leaf surface expansion, which results in considerable decrease in the dry weights of shoot, leaves, and roots (Kandil et al., 2012). This can be linked to the limited supply of metabolites to young growing tissues. Metabolic production usually occur within the leaves and can be affected significantly at high salt stress conditions either due to the low water uptake or toxic effect of $\mathrm{NaCl}$ concentration (Hassen et al., 2014).

The results of this study also show decrease in chlorophyll content with the increasing salinity levels in all tested quinoa genotypes. This can be attributed to the fact that at the higher salinity levels, plants increase generation of reactive oxygen species as by-product. This damages the cellular components and cause chlorophyll degradation and membrane lipid peroxidation, reducing membrane fluidity and selectivity (Verma \& Mishra, 2005). Reduction in chlorophyll content due to metabolic limitations of photosynthesis in leaves at higher salinity levels (above $250 \mathrm{mM}$ ) has also been reported by Munns et al. (2006). In another study decreasing chlorophyll content in trees is associated with aggravated salt stress due to enzymatic chlorophyll degradation (Xu et al., 2011).

The reduction in the photosynthesis under saline conditions mainly occur due to a reduction in leaf area, chlorophyll content and stomatal conductance, and decrease in photosystem II efficiency. The reduction in chlorophyll levels in plants under saline conditions is considered as a typical symptom of oxidative stress and is usually linked with the lack of chlorophyll synthesis, together with the activation of its degradation by the enzyme chlorophyllase (Netondo et al., 2004). The decrease in chlorophyll results in reduced biomass with respect to increasing salinity stress.

The decreases in chlorophyll with increased salt stress were found in Phaseolus vulgaris L., and cereals (Santos, 2004). Cocozza et al. (2013) has also shown that quinoa plant is more resistant to water and salt stresses due to its effective stomatal responses that helps plant growth and protected crop yield (Sai Ram et al., 2002). Jaleel et al. (2008) has shown reductions of chlorophyll content in Catharanthus roseus whereas Nazarbeygi et al. (2011) has got similar results in Canova. Accumulation of salts causes an irreparable damage to the photosynthetic mechanism due to dehydration of cell membranes and closure of stomata which reduces their permeability to $\mathrm{CO}_{2}$ and thus chlorophyll formation.

\section{Conclusions}

There are considerable differences on various plant growth parameters with the increasing salinity on five quinoa genotypes. Results clearly revealed that nearly all parameters measured decreased with increasing levels of salinity stress. Most limiting factor for decreased plant growth was found to be reduction in photosynthesis expressed in the production of chlorophyll. We suggest that in future, plant breeding should focus on developing new genotypes that can withstand salinity and have high antioxidant activity. This study has shown that the performance of ICBA-Q3 is superior followed by ICBA-Q4 and ICBA-Q5. However, further optimization of these genotypes is recommended to enhance their productivity under different agro-ecological conditions. This should include testing of these genotypes for water and heat stresses to assess their suitability for hot and dry climatic conditions prevailing in many regions of Ethiopia. In this study, fresh water is used for all experiments. However, in many areas, availability of fresh water is limited, and poor quality groundwater is used for irrigation. Therefore, it would be worthwhile to evaluate the performance of these quinoa genotypes using different quality irrigation waters.

\section{Acknowledgements}

The authors are thankful to the International Fund for Agriculture Development (IFAD) for providing financial support for this study (Grant No. 2000001100). We are also thankful to the Ministry of Agriculture and the staff of the Werer Research Center of the Ethiopian Institute of Agriculture (EIAR) for their help in conducting these trials and collecting field data. 


\section{References}

Adolf, V. I., Shabala, S., Andersen, M. N., Razzaghi, F., \& Jacobsen, S. E. (2012). Varietal differences of quinoa's tolerance to saline conditions. Plant Soil, 357, 117-129. https://doi.org/10.1007/s11104-012-1133-7

Al-Dakheel, A. J., Hussain, M. I., \& Abdul Rahman, A. Q. (2015). Impact of irrigation water salinity on agronomical and quality attributes of Cenchrus ciliaris L. accessions. Agric. Wat. Manage., 159, $148-154$. https://doi.org/10.1016/j.agwat.2015.06.014

Ali, Y., Aslam, Z., Ashraf, M. Y., \& Tahir, G. R. (2004). Effect of salinity on chlorophyll concentration, leaf area, yield and yield components of rice genotypes grown under saline environment. International Journal of Environmental Science \& Technology, 3, 221-225. https://doi.org/10.1007/BF03325836

Allen, R. G., Pereira, L. S., Raes, D., \& Smith, M. (2006). Crop Evapotranspiration: Guidelines for computing crop water requirements. FAO Publication No. 56 (p. 174). Food and Agricultural Organization, Rome, Italy.

Ashenafi, W., \& Bobe, B. (2016). Studies on Soil Physical Properties of Salt Affected Soil in Amibara Area, Central Rift Valley of Ethiopia. Inter. J. Agric. Sci. Nat. Resour., 3(2), 8-17.

Ashraf, M., \& Foolad, M. R. (2005). Pre-sowing seed treatment-a shotgun approach to improve germination growth and crop yield under saline and none-saline conditions. Advan. Agron., 88, $223-271$. https://doi.org/10.1016/S0065-2113(05)88006-X

Bazile, D., Jacobsen, S. E., \& Verniau, A. (2016). The Global Expansion of Quinoa: Trends and Limits. Frontiers in Plant Science, 7. https://doi.org/10.3389/fpls.2016.00622

Birhane, H. (2017). Salinity Status of Soils of Irrigated Lands, Water Logged Areas and Irrigation Water Quality at Raya Alamata District in Raya Valley, Northern Ethiopia (MSc Thesis, Haramaya University, Haramaya, Ethiopia).

Blake, C. A. (1965). Methods of soil analysis. Part I, American Society of Agronomy. Madison, Wisconsin, USA.

Bosque Sanchez, H., Lemeur, R., Van Damme, P., \& Jacobsen, S. E. (2003). Ecophysiological analysis of drought and salinity stress of quinoa (Chenopodium quinoa Willd.). Food Reviews International, 19, 111-119. https://doi.org/10.1081/FRI-120018874

Breusegem, F., \& Van Dat, J. F. (2006). Reactive oxygen species in plant cell death. Plant Physiology, 41, 384-390. https://doi.org/10.1104/pp.106.078295

Choukr-Allah, R., Rao, N. K., Hirich, A., Shahid, M., Alshankiti, A., Toderich, K., ... Butt, K. U. R. (2016). Quinoa for Marginal Environments: Toward Future Food and Nutritional Security in MENA and Central Asia Regions. Frontiers in Plant Science, 7. https://doi.org/10.3389/fpls.2016.00346

Cocozza, C., Pulvento, C., Lavini, A., Riccardi, M., d'Andria, R., \& Tognetti, R. (2013). Effects of increasing salinity stress and decreasing water availability on ecophysiological traits of quinoa (Chenopodium quinoa W.) grown in a mediterranean-type agroecosystem. Journal of Agronomy and Crop Science, 199, 229-240. https://doi.org/10.1111/jac.12012

Eisa, M. A., Eid, E. H., Abd El-Samad, S. A., Hussain, A. A., Abdel-Ati, N. E., El-Bordeny, S. H., ... El-Naggar, E. M. (2017). Chenopodium quinoa Willd. A new cash crop halophyte for saline regions of Egypt. Australian Journal of Crop Science, 11(03), 343-351.

Ellis, R. A., \& Roberts, E. H. (1981). The quantification of ageing and survival in orthodox seeds. Seed Sci. Technol., 9, 373-409.

FAO (The Food and Agriculture Organization). (2015). Salt-Affected Soils. Food and Agricultural Organization, Rome, Italy.

Frew, A., Tena, A., \& Fentaw, A. (2015). Appraisal and mapping of soil salinity problems in Amibara area of Middle Awash Basin Ethiopia. International Journal of Innovation and Scientific Research, 13(1), 298-314.

Gomez, A., \& Gomez, H. (1984). Statistical analysis for agricultural research (pp. 120-155). John Willy and Sons Inc.

Gómez-Pando, L. R., Álvarez-Castro, R., \& Eguiluz-de la Barra, A. (2010). Effect of Salt Stress on Peruvian Germplasm of Chenopodium quinoa Willd. A Promising Crop. Journal of Agronomy and Crop Science, 196, 391-396. https://doi.org/10.1111/j.1439-037X.2010.00429.x 
Hassen, A., Souguir, M., \& Hannachi, C. (2014). Effect of Salt Stress (NaCl) on Germination and Early Seedling Parameters of Three Pepper Genotypes (Capsicum annuum L.). Journal of Stress Physiology and Biochemistry, 10(1), 15-25.

Heluf, G. (1985). Investigation on Salt-affected Soils and Irrigation Water Quality in Melka Sadi-Amibara Plain, Rift Valley Zone of Ethiopia (MSc Thesis, Addis Ababa University, Addis Ababa, Ethiopia).

Jacobsen, S. E. (2017). The scope for adaptation of quinoa in Northern Latitudes of Europe. Journal of Agronomy and Crop Science, 203, 603-613. https://doi.org/10.1111/jac.12228

Jacobsen, S. E., Mujica, A., \& Jensen, C. R. (2003). The resistance of quinoa (Chenopodium quinoa Willd) to adverse abiotic factors. Food Reviews International, 19(1-2), 99-109. https://doi.org/10.1081/FRI-1200 18872

Jaleel, C. A., Sankar, B., Sridharan, R., \& Panneerselvam, R. (2008). Soil salinity alters growth, chlorophyll content, and secondary metabolite accumulation in Catharanthus roseus. Turkish Journal of Biology, 32(2), 79-83.

Kandil, A. A., Sharif, A. E., Abido, W. A. E., \& İbrahim, M. M. (2012). Effect of salinity on seed germination and seedling characters of some forage sorghum genotypes. International Journal of Agriculture Sciences, 4(7), 306-311. https://doi.org/10.9735/0975-3710.4.7.306-311

Munns, R., \& Tester, M. (2008). Mechanisms of salinity tolerance. Annu. Rev. Plant Biol., 59, 651-681. https://doi.org/10.1146/annurev.arplant.59.032607.092911

Munns, R., James, R. A., \& Läuchli, A. (2006). Approaches to increasing the salt tolerance of wheat and other cereals. Journal of Experimental Botany, 57, 1025-1043. https://doi.org/10.1093/jxb/erj100

Nazarbeygi, E., Yazdi, H. L., Naseri, R., \& Soleimani, R. (2011). The effects of different levels of salinity on proline and A-, B-chlorophylls in Canola. American-Eurasian Journal of Agricultural \& Environmental Sciences, $10(1), 70-74$.

Netondo, G. W., Onyango, J. C., \& Beck, E. (2004). Sorghum and salinity: II. Gas exchange and chlorophyll fluorescence of sorghum under salt stress. Crop Sci., 44, 806-811. https://doi.org/10.2135/cropsci2004.0806

Qadir, M., \& Oster, J. D. (2004). Crop and irrigation management strategies for salinesodic soils and waters aimed at environmentally sustainable agriculture. Sci. Total Environ., 323(1\&3), 1-19. https://doi.org/ 10.1016/j.scitotenv.2003.10.012

Qadir, M., Quillerou, E., Nangia, V., Murtaza, G., Singh, M., \& Thomas, R. J. (2014). Economics of salt-induced land degradation and restoration. Nat. Res. Forum, 38, 282-295. https://doi.org/10.1111/1477-8947.12054

Rhoades, J. D., Chanduvi, F., \& Lesch, S. (1999). Soil Salinity Assessment: Methods and Interpretation of Electrical Conductivity Measurements. FAO Irrigation and Drainage Paper 57. Rome, Italy.

Ruiz, K., Biondi, S., Oses, R., Acuña-Rodríguez, I., Antognoni, F., Martinez-Mosqueira, E., ... Molina-Montenegro, M. (2014). Quinoa biodiversity and sustainability for food security under climate change: A review. Agron Sustain Dev., 34, 349-359. https://doi.org/10.1007/s13593-013-0195-0

Sai Ram, R., Veerabhadra, R. K., \& Srivastava, G. C. (2002). Differential response of wheat genotypes to long term salinity stress in relation to oxidative stress, antioxidant activity and osmolyte concentration. Plant Science, 5, 1037-1046. https://doi.org/10.1016/S0168-9452(02)00278-9

Santos, C. V. (2004). Regulation of chlorophyll biosynthesis and degradation by salt stress in sunflower leaves. Scientia Horticulturae, 103, 93-99. https://doi.org/10.1016/j.scienta.2004.04.009

Scanlin, L., \& Lewis, K. A. (2017). Quinoa as a Sustainable Protein Source. Sustainable Protein Sources (pp. 223-238). Elsevier. https://doi.org/10.1016/B978-0-12-802778-3.00014-7

Shabala, S., Hariadi, Y., \& Jacobsen, S. E. (2013). Genotypic difference in salinity tolerance in quinoa is determined by differential control of xylem $\mathrm{Na}^{+}$loading and stomatal density. J. Plant Physio., 170, 906-914. https://doi.org/10.1016/j.jplph.2013.01.014

Sileshi, A. (2016). Status of salt-affected soils, irrigation water quality and land suitability of Dubti-Tendaho Area (PhD Dissertation, Haramaya University, Ethiopia).

Smirnoff, N. (1996). Botanical briefing: the function and metabolism of ascorbic acid in plants. Annals of Botany, 78, 661-669. https://doi.org/10.1006/anbo.1996.0175 
UNICEF (United Nations Children's Fund). (2016). The State of the World's Children 2016: A fair chance for every child. New York, USA. https://doi.org/10.18356/4fb40cfa-en

United Stated Soil Laboratory Staff. (1954). Diagnosis and improvement of saline and alkali soils. USDA Agriculture Handbook 60. USDA, Washington, D.C.

Van Reewijk, L. P. (1992). Procedures for soil analysis (3rd ed.). International Soil Reference Center, Wageningen, Netherlands.

Vega-Gálvez, A., Miranda, M., Vergara, J., Uribe, E., Puente, L., \& Martínez, E. A. (2010). Nutrition facts and functional potential of quinoa (Chenopodium quinoa Willd.), an ancient Andean grain: A review. Journal of the Science of Food and Agriculture, 90, 2541-2547. https://doi.org/10.1002/jsfa.4158

Verma, S., \& Mishra, S. N. (2005). Putrescine alleviation of growth in salt stressed Brassica juncea by inducing antioxidative defense system. J. Plant Physio., 162, 669-677. https://doi.org/10.1016/j.jplph.2004.08.008

Wilson, C., Read, J. J., \& Abo-Kassem, E. (2002). Effect of mixed-salt salinity on growth and ion relations of a quinoa and a wheat variety. J. Plant Nutrition, 25(12), 2689-2704. https://doi.org/10.1081/PLN-12 0015532

Wondimagegne, C., \& Mnalku, A. (2012). Selected Physical and Chemical Characteristics of Soils of the Middle Awash Irrigated Farm. Ethiopian J. of Agriculture Science, 22, 127-142.

Xu, Z. Z., Zhou, G. S., Han, G., \& Li, Y. (2011). Photosynthetic potential and its association with lipid peroxidation in response to high temperature at different leaf ages in maize. J. Plant Growth Regul., 30, 41-50. https://doi.org/10.1007/s00344-010-9167-7

\section{Copyrights}

Copyright for this article is retained by the author(s), with first publication rights granted to the journal.

This is an open-access article distributed under the terms and conditions of the Creative Commons Attribution license (http://creativecommons.org/licenses/by/4.0/). 